\title{
TRADITIONAL MEDICINAL PLANTS AS PROMISING SOURCE OF IMMUNOMODULATOR AGAINST COVID-19
}

\author{
Shikha Tiwari, N. K. Dubey* \\ Centre of Advanced Studies in Botany, Institute of Science, Banaras Hindu University, Varanasi-221005.
}

Received - September 20, 2020; Revision - October 22, 2020; Accepted - November 02, 2020

Available Online - November 04, 2020

DOI: http://dx.doi.org/10.18006/2020.8(Spl-1-SARS-CoV-2).S126.S138

KEYWORDS
Ethnomedicine
Herbs
Indian spices
Immunity booster
SARS-CoV-2

\begin{abstract}
Outbreak of novel corona virus (Covid-19) or Severe Acute Respiratory Syndrome corona virus 2 (SARS CoV-2) was noticed in China at the end of 2019 and has now become one of the major global health threat. Although, Covid-19 virus imposes detrimental effects to all groups of persons irrespective of their age, sex, race and body physic. Immuno-compromised people are reported to be severely affected in comparison to immunocompetent persons, suggesting immunity as a major player against SARS CoV-2. Despite of great efforts and intensive researches carried all over the world, so far there are no clinically approved vaccines or specific therapeutic drugs available for Covid-19. In this regard, different traditional medicinal plants, which are vast reservoir of bioactive compounds with broad therapeutic and immunomodulatory properties, have been emerged as boon to combat with Covid-19. Along with pharmacological properties and easily availability, safety paradigm of ethnomedicinal plants makes them highly preferable immediate remedy to enhance immunity and compete with novel corona virus. Use of traditional Indian spices has been also realized as effective and safer strategy in order to boost immunity and deal with highly terrible current Covid-19 situation. Hence, there is need to boost the efficacy of the traditionally used plant based immunomodulators against Covid-19 pandemic incorporating modern biotechnological and pharmacological tools so as to enhance bioavailability and practical applicability. The present article deals with general feature of SARS CoV-2 along with recent reports on efficacy of traditional medicinal plants as well as Indian spices as an effective immunomodulator for Covid-19.
\end{abstract}

* Corresponding author

E-mail: nkdubeybhu@gmail.com (N. K. Dubey)

Peer review under responsibility of Journal of Experimental Biology and Agricultural Sciences.

Production and Hosting by Horizon Publisher India [HPI] (http://www.horizonpublisherindia.in/).

All rights reserved.
All the articles published by Journal of Experimental Biology and Agricultural Sciences are licensed under a Creative Commons Attribution-NonCommercial 4.0 International License Based on a work at www.jebas.org.

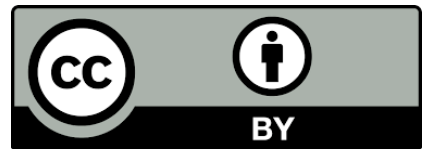




\section{Introduction}

Covid-19 or novel corona virus infection which was first reported in the beginning of December, 2019 from an emerging business hub of Wuhan city of Hubei province of China (Lin et al., 2020) has currently become a major global health threat. Novel corona virus is spreading rapidly all over the world and infects people of all ages irrespective of their age, sex and community. World Health Organization (WHO) has declared Covid-19 as global pandemic which leads to create highly alarming and challenging situation to the medical practitioners, politicians and as well as scientists all over the world (Dhama et al., 2020; Malik et al., 2020). Despite of highly concerned research towards prevention measure of Covid-19, so far no effective vaccine or drug has been discovered in modern allopathic system, though efforts are being made continuously in this direction (Rodriguez-Morales et al. 2020; Rabaan et al., 2020a; Yatoo et al., 2020). It has been experienced that immunity of an individual plays a vital role to fight against SARS corona virus-2 through declining its pathogenic potency inside host (Florindo et al., 2020). Therefore, until the discovery of promising therapeutic treatment and vaccine for the virus, people are looking towards herbal formulations in order to enhance the immunity of their body system so that they can survive under this critical health emergency situation. Traditional medicinal plants or ethnomedicines have miraculous treasure to serve as immunity booster due to the presence of numerous bioactive compounds such as terpenes, tannins, flavonoids, alkaloids, saponins, phenols, glycosides and thiosulfates (Dhama et al., 2015; Dhama et al., 2018; Tiwari et al., 2018; Mahapatra et al., 2019). Besides, several phytocopounds such as silvestrol, lycorine, scutellarein, myricetin, quercitin, caffeic acid and tryptanthrin are reported to have promising antiviral potency (Mani et al., 2020). Further, Ginkgetin and tetrahydroxy flavones, biflavonoid of Ginkgo biloba, indole alkaloid from Uncaria rhynchophylla, thalimonine from Thalictrum simplex, polyphenolic constituent of Geranium sanguineuma and lignans such as rhinacanthin $\mathrm{E}$ and $\mathrm{F}$ from Rhinacanthus nasutusare along with several other phytoconstituents such as betulinic acid, agastanol, calanolide, glycyrrhizin, ursolic acid and punicalagin are also reported to have diverse array of efficacious antiviral potency (Dhama et al., 2018). Under present challenging situation of novel corona virus, different traditionally used medicinal plants have been recognized as potential candidates for developing effective and secure remedies against the devastating pandemic, thereby, inspiring scientists in formulation of effective immunity booster as an immediate preventive tool against SARS CoV-2 virus. In China nearly 60,000 confirmed corona cases are treated by traditional medicinal system (Ren et al., 2020). Chinese herbal medicines due to their therapeutic potency and practical applicability against Covid-19 have enforced Chinese health department to implement an program regarding integration of Chinese herbal medicine and western medicine in order to boost drug efficacy against Covid-19 (Li et al., 2020). Several Chinese traditional medicinal formulations i.e. Jinhua Qinggan capsules and Qingfei Paidu decoction are frequently prescribed to Covid patients having effective therapeutic potency and recovery rate (Zhang et al., 2020). Another Chinese medicine i.e. Yupingfeng San comprising three herbs Atractylodes, Astragalus and Fangfeng maintained lung immunity and proved to be as effective drug against novel corona virus that mainly target lungs (Xu \& Zhang, 2020). Similarly, Indian government ministry of Ayurveda, yoga and naturopathy, Unani, Sidhha and Homeopathy (AYUSH) also recommend Ayurveda as well as homeopathy and Unani as better approach to manage Covid-19 cases. Hence considering the herbal formulations as new hope in the current alarming situation of novel corona virus, the present article explores some traditional medicinal plant as an effective weapon against corona.

\section{Novel corona virus: general structure and disease symptoms}

Corona virus $(\mathrm{CoVs})$ is small size virus of $65-125 \mathrm{~nm}$ diameters having single stranded RNA as their genetic material. CoV genome is reported to be the largest genome among known RNA viruses ranging between $26-32 \mathrm{~kb}$ (Chen et al., 2020a). Virion is generally enveloped by phaspholipid bilayer having genomic RNA and nucleocapsid protein $(\mathrm{N})$ inside it. Different structural proteins including membrane protein (M), envelope protein (E) and spike glycoprotein (S) are also found embedded in the envelope. These proteins have different functions such as Nucleocapsid protein $(\mathrm{N})$ involved in packaging of viral genome and helps in pathogenicity of virus through inhibiting interferon function (IFN), Membrane protein $(\mathrm{M})$ responsible for shaping of virion, envelope protein (E) responsible for virion assembly and release while Envelope glycoprotein (S) is the key protein responsible for recognizing host cell receptor (Alanagreh et al., 2020). Corona is derived from the latin word Coronam means crown, which describes the presence of spike glycoproteins on the envelope of members of corona viruses giving viruses a crown like appearance (Cascella et al., 2020). CoVs belongs to the largest family of order nidovirales i.e. coronaviridae and sub family orthocoronaviridae. Subfamily orthoviridae basically comprised of four genera including alpha corona virus $(\alpha-\mathrm{CoVs})$, beta corona virus $(\beta-\mathrm{CoVs})$, gamma corona virus $(\gamma-\mathrm{CoVs})$ and delta coronavirus $(\delta-\mathrm{CoVs})$ among which $\alpha-\mathrm{CoVs}$ and $\beta-\mathrm{CoVs}$ is associated with mammal such as bat while $\gamma$ - $\mathrm{CoVs}$ and $\delta$ - $\mathrm{CoVs}$ is associated with birds and swine gene pool (Banerjee et al., 2019; Dhama et al., 2020). There are two recent outbreaks of viral pneumonia epidemics associated with $\beta$-CoVs i.e. severe acute respiratory syndrome (SARS CoV) and Middle East respiratory syndrome (MERS CoV) reported in year 2002 from China and in year 2012 from Saudi Arab respectively. Later on through genome sequencing it is confirmed that virus associated with Covid -19 named as novel corona virus (nCoV), 
severe acute respiratory syndrome corona virus 2 (SARS-CoV-2) and 2019-novel coronavirus (2019-nCoV) also belongs to $\beta$-CoVs group (Wu et al., 2020). SARS and MERS both are originated from bats and have an intermediate host's civet and camel respectively as a human infecting intermediate. SARS CoV-2 show distinct characteristics from earlier reported SARS CoV (around 79\% similarities) and MERS CoV virus (around 50\% similarity) in phylogenetic analysis (Rabaan et al., 2020b). SARS CoV-2 virus shows $96.2 \%$ genetic similarity with the bat corona virus supporting its origin from bat and its transmission to human through intermediate animal hosts (Guo et al., 2020). Continuous mutation in genome of virus will also impose major challenge to researchers to discover its specific treatment. This novel corona virus has challenged the economy, medical facilities and societal health of the nations. Due to pandemic situations, affected counties are implementing lockdown to control spreading of disease but this lockdown have also negative influence on economy of nation due to dropped industrial production. Further, restrictions in traveling caused loss of millions of dollar to airlines and tourism sectors Some countries are also facing shortage of some basic required items like mask, sanitizer and medicines due to ban on transportation. Corona virus also causes big social threat and affects mental health of persons as social gathering in form of scientific conferences, marriage parties, business meetings and sports events are suggested to avoid. Hence, Covid-19 negatively influences not only the health and economy of nation but also have negative effect on all sectors of life. This deadly disease become to be a major challenge for researchers and scientists to discover its prevention measures as the virus is fast replicating inside the host cell and have also high rate of mutagenesis and structure changing properties (Helmy et al., 2020). In addition virus has also potential to survive under wide range of environmental conditions which create major barrier in investigation of disease and therapeutic treatments (Vellingiri et al., 2020).

Covid-19 virus attaches itself to the host receptor protein i.e. angiotensin converting enzyme (ACE 2) of bronchial epithelial cells through its glycoprotein spikes which is the crucial step in pathogenesis of virus. After entering inside the host, virus replicates and leads to produce symptoms. SARS CoV-2 is having 10-20 times higher binding efficiency with ACE 2 in comparison to SARS CoV leading to enhance its infectious potential (Jin et al., 2020). Huang et al. (2020) reported that critically ill patients with SARS CoV-2 virus have enhanced concentration of cytokine and chemokines in plasma, known as cytokine storm which will leads to disease severity, multi organ failure as well as mortality. The clinical feature of Covid-19 is varied with patients ranging from asymptomatic in immunocompetent person to severe respiratory disorders and multi organ dysfunction in immunocompromised persons. The common clinical feature of Covid-19 includes fever, sore throat, coughing, fatigue and headache which remain for several weeks (Singhal, 2020). However, in poor immunity people virus can cause severe respiratory problems such as pneumonia and bronchitis and even lead to death. People of all age groups are prone towards the Covid-19 virus although lower age group and overage people are more susceptible. Although enhanced immunity may not prevent the attack of virus, however it controls the severity of virus and also helps in fast recovery. Infection is transmitted either through inhalation of coughing and sneezing droplet from infected persons or through touching contaminated surface and then touching the nose, mouth and eyes. Subsequently, stools and contaminated water is also reported to be an important transmission source for virus.

\section{Phytomedicines: as a promising warrior against Covid-19}

Herbal medicines due to its miraculous antiviral potency, has been used since ancient time to treat viral diseases. Although role of modern allopathic medicines in human health management cannot be neglected but their negative consequences on health can also not be ignored. Thus, due to easy accessibility, economical benefits, less chances of toxicity, traditional medicinal system or phytomedicines are highly preferred to synthetic drugs. In allopathic systems there is always need to search for a new drug as the virus easily develop resistance against the single compound, however, in case of herbal formulations, which is comprised of several phytoconstituents virus have less chance to develop resistance and have also tremendous potency to inhibit different growth stages of virus (Akram et al., 2018). There are several ethnomedicinal plants such as Murraya koenigii, Euphorbia hirta, Curcuma longa, Zingiber officinale, Adhatoda zeylanica, Acalypha indica, Allium sepa, Coriandrum sativum, Ocimum basilicum Allium sativum etc. recommended to have effective therapeutic potential in order to treat breathing problems, cough and cold (Murthy \& Vidyasagar, 2013; Dhama et al., 2018). In addition Alstonia scholaris, Rubia cordifolia, Swertia chirata, Cassia occidentalis, Eclipta erecta, Achyranthes aspera, Piper betel, Azadirachta indica and Lantana involucrate are some Indian herbal medicines reported to have potent antipyretic property (Umashanker \& Shruti, 2011). Further, Phyllanthus amarus, Withania somnifera, Tinospora cardifolia, Curcuma longa, Emblica officinalis, Glycyrrhiza glabra and Andrographis paniculata are some ancient Indian medicinal plants reported to have broad antiviral and immunity bosting properties (Gangal et al., 2020). There are several plants such as Gauzuma ulmifolia, Achyranthus aspera, Ficus religiosa, Carissa edulis, Punica granatum, Moringa oleifera etc reported to have an efficacious antiviral potency (Divya et al., 2020). Several natural phytoconstituents like flavonoids, comprising variable phenolic groups are also reported to have broad bioactivity in terms of antibacterial, antiviral, anti-inflammatory, anticancerous and antioxidant potency, in this respect Bhowmik et al. (2020) explored hesperedin, quercetin, naringin and epigallocatechin gallate flavonoids as an efficient therapeutic agent to control rapid spread of 
SARS CoV-2 through preventing entry of virus inside host cell. Flavonoid based phytomedicines such as equivir, caflanone, myricetin and linebacker are also reported to have promising therapeutic value against Covid-19, because it inhibits viral entry inside host through strongly binding to helicase, protease and spike proteins on ACE2 receptor and ultimately leading to change its conformation (Ngwa et al., 2020). Bailly \& Vergoten (2020) reported Glycyrrhizin, triterpenoid saponin isolated from Glycyrrhiza glabra, G. inflata and G. uralensis as a potential phytomedicine to combat Covid-19 pandemic due to its antiviral and anti inflammatory property; further through molecular docking it is also revealed that efficiently binding of glycyrrhizin to ACE2 receptor prevent attachment of virus to host ultimately leading to prevent spread of disease. In addition, glycyrrhizin is also categorized as generally recognized as safe (GRAS) by FDA suggesting it as safe compound and is reported as potential source to reduce disease severity of covid-19 through blocking entry points of covid-19 virus through different modes such as down regulation of ACE2 receptor protein expression and cytokine storm, prevention of intracellular reactive oxygen species accumulation, and up regulation of endogenous interferon as a defense chemical (Murck, 2020; LuoLiu \& Li, 2020). Sinha et al. (2020) reported glyasperin A, another phytoconstituent of G. glabra that inhibited viral replication after entering inside host in contrary to glycyrrhizin which prevents entry of virus inside host. Glycosides and flavonoids constituents of Allium sativum, Ficus racemose and Salvia officinalis are reported to have potent DNA gyrase damaging efficacy and thus suggested being one of the possible remedy against deadly novel corona virus (Devansh, 2020). Further, Jena et al. (2020) reported polyphenolic phytoproducts such as curcumin and catechin to be a potential component in drug development against novel corona virus as these biomolecules potentially inhibit host viral interaction due to its high binding affinity with both viral $\mathrm{S}$ protein and host ACE2 receptor protein. Several phytocomponents of Chinese medicinal plants such as amaranthin from Amaranthus tricolor, calceolarioside B from Flaxinus sieboldiana, methyl rosmarinate from Hyptis atrorubens Poit and licoleafol from Glycyrrhiza uralensis are also reported to have inhibitory role in viral replication suggesting them to be a novel natural therapeutic drug against Covid-19 (Ul Qamar et al., 2020). Notably, several ethnomedicinal plants or their therapeutic benefits are vanishes over time due to lack of proper documentation as the ethnomedicinal knowledge is transferred over generations orally. Intensive research on antiviral, anti-inflammatory and antioxidant properties of ethnomedicinal herbs strongly support them as better remedy to different disease and also as a favorable treatment of Covid-19. Moreover, standard clinical trials are strongly recommended in order to scientifically authenticate its pharmacological efficacy. Figure 1 represents the general feature of virus as well as characteristics of traditional medicinal plants as possible candidate against Covid-19.

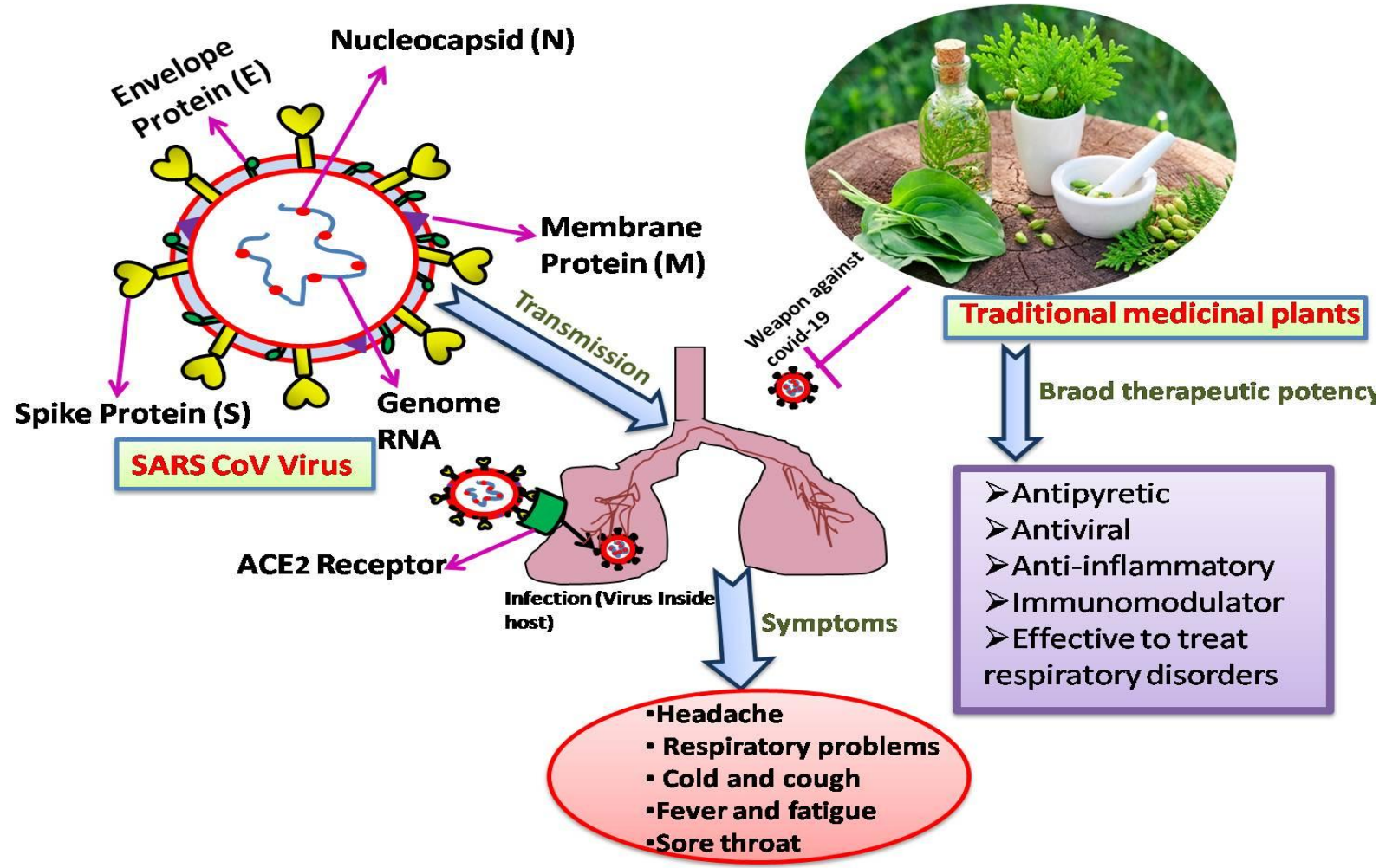

Figure1: General feature of SARS CoV-2 and traditional medicinal plants as potent warrior against covid-19 pandemic

Journal of Experimental Biology and Agricultural Sciences

http://www.jebas.org 


\section{Traditional medicinal plants: as potential immunomodulators}

Ayurveda is having a vast historical perspective in Indian healthcare system and supposed to be originated in India around 4500 to $1600 \mathrm{BC}$ as mentioned in ancient spiritual text Rigveda (Mishra et al., 2001). Indian subcontinents are vast repository of medicinal plants where $70 \%$ of populations are still relying on Ayurvedic system of medicine for their primary health care needs (Pandey et al., 2013). At present scenario phytoproduct based formulations are highly preferred to allopathic drugs globally due to their therapeutic efficiency, cost effectiveness and safety paradigm and nearly $25 \%$ worldwide prescribed drugs are based on phytoproducts (Sen \& Chakraborty, 2017). Indian traditional medicinal systems including Ayurveda, Sidhha, Unani, Yoga, Naturopathy and Homeopathy, used effectively by ancient health practitioners against different chronic diseases. Although traditional medicinal system is having historical background, due to its hidden treasure nearly $80 \%$ of world population preferred phytomedicines for their primary health care (Khan \& Yadava, 2010). Importance of ancient ethnomedicinal knowledge is scientifically proved at several times one of burning example is therapeutically important Terminalia chebula, Tinospora cardifolia, Emblica officinalis and Terminalia bellirica medicinal plants which are used by ethnic tribes of chhota bhangal in ancient time based on their ethnomedicinal knowledge without having much scientific knowledge and they described importance of these plants by saying that people never get diseased if they are having these plants in their region (Uniyal et al., 2006). Ayurveda is basically plant based medicinal system having no any side effect and highly encouraged during this Covid-19 pandemic. In ancient healing system of India i.e. Ayurveda Covid-19 may be mentioned as Janapadodhwamsa vikara (epidemic disease) which is a situation in which contaminated environmental factors i.e. land, water and air may lead to manifest disease in large population leading to broad devastating situation. Although, there is no direct implementation of Ayurvedic medicine to treat coronavirus disease, however, there is evidence from New York where positive corona patient completely relieved from Covid-19 symptoms after ayurvedic treatment (Girija \& Shivan, 2020). In Ayurveda there is five different ways mentioned for uptake of medicine that is either in form of decoction (kwath or kadha), kalka (in form of paste), swaras (Juice), phant (an herb infused concoction) and hima (an herb induced concoction). Decoction is an oldest form of medicine prepared from herb or spices and highly recommended by AYUSH Ministry, Government of India as an immunobooster or anti-inflammatory cure to combat crisis of Covid-19 (Ayush, 2020). Ocimum sanctum, Cinnamomum verum, Allium sepa, Allium sativum, Glycirrhiza glabra, Piper nigrum, Curcuma longa and Daucus maritimus are some traditionally known plants having antiviral properties and their aquous extracts are recommended to be effective against common cold and flu (Ali \& Alharbi, 2020). Under the current pandemic situation when there is lack of effective preventive and curative medicine for Covid-19, immune system of an individual is the strongest weapon to fight against the pandemic situation. Immunity has drastic effect to control pathogenesis of Covid-19 at both early non severe stage and later severe stage. At early stage strong immunity prevents further spread of virus while in later stage strong immunity grave the consequences of cytokine storm. There are several medicinal plants reported in Ayurveda as Rasayana or immunomodulator such as Panax ginseng, Achillea millefolium, Andrographis paniculata, Asperagus racemosus, Bauhinia variegata, Hyptis suaveolens, Cleome gynandra, Alternanthera tenella, Abutilon indicum, Heracleum persicum, Lagenaria siceraria and Chlorophytum borivilianum (Kumar et al., 2012). Considering importance of boosted immunity against Covid-19 situation Ayush ministry, India On march 31, 2020 has issued an advisory on variety of immunity enhancing steps and later on also recommended herbal formulation Ayush kwath or Ayush Joshanda or Ayush kudineer which is mixture of four medicinal herb i.e. Ocimum sanctum, Cinnamomum zeylanicum, Zingiber officinale and Piper nigrum (Gautam et al., 2020). Ayush kwath has both the principle properties of ayurveda, Swasthasyorjaskara i.e. immunity strengthening and roganut i.e. disease alleviation. In Ayurveda leading treatment for any epidemic condition includes Rasayana chikitsa (Immune modulating therapy), Panchakarma (five process of purification) and Sadvritta (good conduct). Immune modulatory drugs are the substances that modulate immune system. Rasyana dravyas of ayurveda such as Tinospora cardifolia, Glycyrrhiza glabra, Andrographis paniculata, Boerhaavia diffusa, Ocimum sanctum, Withania somnifera are recommended to be supportive in Covid-19 (Niraj \& Varsha, 2020). Recently Yog Guru Baba Ramdev suggested an Ayurvedic drug coronil under an umbrella brand Patanjali comprised of Tinospora cardifolia, Ocimum tenuiflorum and Withania somnifera and is approved by AYUSH Ministry India to be sold as immuobooster against corona (Baravkar et al., 2020). Another important herbal formulation strongly suggested for deadly disease is Chawanprash which is known as ageless wonder in Ayurveda, and comprises mixture of several nutritive phytoconstituents acting singly or synergistically as immunomodulator, free radical scavenger and anti aging agent (Sharma et al., 2019). Pharmacological efficacy of herbal medicines is based on its phytoconstituents. At present time one of the highly recommended Ayurvedic immune booster for Covid-19 is Ayurvedic kadha which is basically comprised of Ocimum sanctum, Piper nigrum, Elletaria cardamomum, Zingiber officinale, Syzygium aromaticum, Withania somnifera and Tinospora cardifolia. Maurya \& Sharma (2020) through molecular docking technique analyzed antiviral efficacy of 
bioactives such as withanolid, withaferin $\mathrm{A}$, withanone, quercetin, piperine, vicenin, campesterol, somniferin, isopiperine etc present in kadha and found its anti-inflammatory against virus through binding with various inflammatory mediators or nucleocapsid protein of virus. Besides, these phytochemicals also impart inhibitory effect on host viral interaction due to its high binding affinity with viral spike protein, host receptor protein and furin protein, facilitator of spike and ACE2 interaction. Similarly, Lycorine an bioactive constituent of Locis radiate is reported to be effective against SARS CoV as well as having anticancerous properties (Lau et al., 2008), another active component i.e. emodine found in extracts of Polygonum multiflorum and Rheum officinale, scutellarin, tetra-O-galloyl- $\beta$ D glucose (TGG) from Galla chinensis, Baicallin from Scutellaria baicalensis, luteolin from Veronicalina riifolia is also reported as effective drug against SARS $\mathrm{CoV}$ as it inhibit binding of spike protein with host cells (Mirzaie et al., 2020). Further in view of imunomodulatory activity polynutrient based novel combination of curcumin, glycyrhhizic acid and vitamin $\mathrm{C}$ is also reported to prevent cytokine storm to serve as beneficial approach against novel coronavirus (Chen et al., 2020b). Thus, phytoproducts are also supposed to be a promising candidate against corona virus as it has an immunobooster property. Besides several recommended traditional medicinal plants some plant based products including fruits like orange, kiwi, guavava, papaya and vegetables like beet root, spinach and cauliflower are also recommended to be taken during this pandemic situation as these are rich source of vitamin $c$ that enhance immunity of person (Mahim et al., 2013; Rahal et al., 2014). In addition, red onion, green tea, black tea, green leafy vegetables, apples and grapes are found to be rich source of biflavonoid i.e. quercetin which is reported to prevent viral infection including SARS CoV (Arsad et al., 2020). Further, Panax ginseng, Aloe vera, Angelica gigas, Astragalus membranaceus, Scutellaria baicalensis, Lawsonia alba, Plumbago zeylanica and Cissampelos pareira are also some other immunomodulatory herbs reported as enhancer of body stamina to fight against novel corona virus (Panyod et al., 2020). Apart from broad therapeutic values Ayurvedic herbs also have a disinfectant property which is one of highly requiring area during this pandemic, powder of Curcuma longa, seeds of Trachyspermum ammi, peel of Allium sativum and Styrax benzoin resin together used for fumigation considered to be an effective disinfectant (Rastogi et al., 2020). Some common Indian medicinal plants with their therapeutic potency that may be used as promising candidate against corona virus disease are summarized in Table -1.

\section{Indian Spices as traditional immunobooster against Covid-19}

Indian spices are having vast medicinal properties and are frequently used from ancient time as energy as well as immunity booster to combat common problems of cold, cough and flu.
Hence, during the worst Covid-19 situation, Indian spices appeared as gift of India's ancient wisdom for whole world which have potency to enhances immunity and prepare body to fight against SARS CoV-2 virus. Presently under situation when known remedy is lacking against onslaught of SARS CoV-2 Indian spices are best to be used, as they are easily present in every kitchen and have potent immunity boosting properties along with antiviral and several other therapeutic values. Thus, daily basis use of these miraculous therapeutic spices might be useful in mitigating risk of Covid-19. Some commonly used Indian spices which might be served as an efficacious immunomodulatory agent against Covid19 are as follows-

\subsection{Curcuma longa (Turmeric)}

Turmeric is one of the most common Indian spices which belong to family Zingiberaceae and commonly used as household treatment against cold, sore throat and respiratory problems. Curcumin is its major active principle and reported to have several therapeutic values such as antioxidant, anti-inflammatory, antimicrobial, antiseptic, anticancerous and immunity booster (Sahoo et al., 2020). In addition, through in silico analyses major compounds of turmeric are also reported to have efficacious antiviral potency against novel corona virus because it effectively suppress virulence of virus by inhibiting its main protease activity (Gupta et al., 2020b). Turmeric milk along with boiled milk is also suggested as better remedy against cough, cold and respiratory problems. Therefore, turmeric might be an effective immunity booster against Covid-19

\subsection{Allium sativum (Garlic)}

Garlic, besides its quality to be used as food additive also have broad therapeutic properties as cardio-protectant, antioxidant, anti inflammatory, anti viral, anti-cancerous and as imunomodulatory substance. Allicin, an organo sulphur compound present in garlic protect body from common cold and flu through up regulating immunity of body. Garlic is reported to exhibit immnunomodulatory effect through regulating cytokine and chemokines level inside body (Donma \& Donma, 2020) suggesting garlic to be promising candidate in order to deal with Covid-19 mediated cytokine storm.

\subsection{Syzygium aromaticum (Clove)}

It is a dried flower bud, used widely to prepare spicy dishes due to its intense taste and fragrance. In addition, clove having eugenol as one of its phytoconstituent, reported to have wide array of therapeutic properties such as analgesic, anti inflammatory, immunomodulatory and better remedy for respiratory disorders (Dibazar et al., 2014). Besides, clove is also having an efficient antiviral and antipyretic potency. 
Table1 1 Some potential Indian medicinal plants used effectively against Covid-19

\begin{tabular}{|c|c|c|c|c|}
\hline $\begin{array}{l}\text { S. } \\
\text { No. }\end{array}$ & $\begin{array}{l}\text { Traditional Medicinal } \\
\text { Plants }\end{array}$ & Family & Physiological effect & References \\
\hline 1 & $\begin{array}{l}\text { Tinospora cardifolia } \\
\text { (Guduchi) }\end{array}$ & Menispermaceae & $\begin{array}{l}\text { Berberine, tinosporin, choline, tinosponone and palmitine like } \\
\text { phytoconstituents contributed to its antioxidant, anti-inflammatory and } \\
\text { immunomodulatory effects. Besides molecular docking revealed it as potent } \\
\text { inhibitor of SARS CoV-2 main protease. }\end{array}$ & $\begin{array}{l}\text { Krupanidhi et al. } \\
\qquad(2020)\end{array}$ \\
\hline 2 & $\begin{array}{l}\text { Curcuma longa } \\
\text { (Haldi) }\end{array}$ & Zingiberaceae & $\begin{array}{l}\text { Curcumin as an active principle have anti-inflammatory, antiviral, } \\
\text { antioxidant and anticancerous property. Besides also used in respiratory } \\
\text { disorders. Its efficacy against dengue, influenza, HIV and several other viral } \\
\text { diseases access its value as effective drug against Covid-19. }\end{array}$ & $\begin{array}{l}\text { Gupta et al. } \\
\text { (2020a) }\end{array}$ \\
\hline 3 & $\begin{array}{l}\text { Syzigium aromaticum } \\
\text { (clove) }\end{array}$ & Myrtaceae & $\begin{array}{l}\text { Eugenol as major bioactive component and clove is reported to have anti } \\
\text { inflammatory, anticancerous antioxidant and antipyretic property. }\end{array}$ & $\begin{array}{l}\text { Mittal et al. } \\
(2014)\end{array}$ \\
\hline 4 & $\begin{array}{l}\text { Cinnamomum verum } \\
\text { (Cinnamon) }\end{array}$ & Lauraceae & $\begin{array}{l}\text { Cinnamaldehyde and eugenola as active principle enhance therapeutic } \\
\text { efficacy of herbal material in terms of antimuatgenic, antiviral, } \\
\text { immunemodulatory, and antipyretic potency. }\end{array}$ & $\begin{array}{l}\text { Gulcin et al. } \\
\text { (2019) }\end{array}$ \\
\hline 5 & $\begin{array}{l}\text { Andrographis paniculata } \\
\text { (Kalmegh) }\end{array}$ & Acanthaceae & $\begin{array}{l}\text { Plant is having andrographolide as its major bioactive component and } \\
\text { reported to be effective against HIV virus, Herpes virus, and hepatitis B and } \\
\mathrm{C} \text { virus, Influenza A virus. }\end{array}$ & $\begin{array}{l}\text { Gupta et al. } \\
\text { (2017) }\end{array}$ \\
\hline 6 & $\begin{array}{l}\text { Withania somnifera } \\
\text { (Ashwagandha) }\end{array}$ & Solanaceae & $\begin{array}{l}\text { Bioactive components such as withaferin } \mathrm{A} \text {, withanolide series and } \\
\text { withanoside series reported to have rejuvenating, immunity boosting and } \\
\text { antiviral efficacy against Covid-19 through inhibiting main protease deadly } \\
\text { virusof suggesting it as efficacious possible corona drug. }\end{array}$ & $\begin{array}{l}\text { Tripathi et al. } \\
\quad(2020)\end{array}$ \\
\hline 7 & $\begin{array}{l}\text { Allium sativum } \\
\text { (Garlic) }\end{array}$ & Liliaceae & $\begin{array}{l}\text { Prime organosulfur bioactive compound such as allicin, diallyltrisulfide and } \\
\text { azoene and flavonoids such as anthocyanin and quercitins prevents entry as } \\
\text { well as multiplication of virus inside host suggesting it as potent drug source } \\
\text { against Covid-19. }\end{array}$ & $\begin{array}{l}\text { Kaushik \& Singh } \\
\qquad(2020)\end{array}$ \\
\hline 8 & $\begin{array}{l}\text { Glycyrrhiza glabra } \\
\text { (Licorice, Mulaithi) }\end{array}$ & Fabaceae & $\begin{array}{l}\text { Effective in respiratory disorders, fever, stomach problems and also have } \\
\text { anti inflammatory, antioxidant and antiviral properties. }\end{array}$ & $\begin{array}{c}\text { Batiha et al. } \\
(2020)\end{array}$ \\
\hline 9 & $\begin{array}{l}\text { Ocimum sanctum } \\
\quad \text { (Tulsi) }\end{array}$ & Lamiaceae & $\begin{array}{l}\text { Known as Queen of herbs having Antiviral, antioxidant, anti-inflammatory, } \\
\text { immunomodulatory potential and antiasthmatic property. Phytochemicals } \\
\text { such as vincenin, ursolic acid and isorientin through molecular docking } \\
\text { reported to suppress novel corona virus and host interaction safely and } \\
\text { effectively. }\end{array}$ & Shree et al. (2020) \\
\hline 10 & $\begin{array}{l}\text { Zingiber officinale } \\
\quad \text { (Ginger) }\end{array}$ & Zingiberaceae & $\begin{array}{l}\text { Medicinal plant widely used to treat cough, bronchitis, respiratory tract } \\
\text { infection, have anti inflammatory, anticancerous propertyalong with strong } \\
\text { therapeutic potency against Chikungunya virus. }\end{array}$ & $\begin{array}{l}\text { Kaushik et al. } \\
\qquad(2020)\end{array}$ \\
\hline 11 & $\begin{array}{l}\text { Boerhaavia diffusa } \\
\quad \text { (Punarnava) }\end{array}$ & Nyctaginaceae & $\begin{array}{l}\text { Plant used to ameliorate multiple diseases such as pulmonary tuberculosis, } \\
\text { jaundice, cough, kidney disorders and gastric problems. Also have potent } \\
\text { immune stimulatory property. }\end{array}$ & $\begin{array}{c}\text { Nayak \& } \\
\text { Thirunavoukkaras } \\
\text { u (2016) }\end{array}$ \\
\hline 12 & $\begin{array}{l}\text { Vitex negundo } \\
\text { (Nirgundi) }\end{array}$ & Verbenaceae & $\begin{array}{l}\text { Plant is highly important and used frequently even in allopathic drug } \\
\text { formulations. Efficacious in clod, flu, asthma, fever, headache, dysentery } \\
\text { and even as immunity stimulator. }\end{array}$ & $\begin{array}{l}\text { Maurya \& Rao } \\
\quad(2019)\end{array}$ \\
\hline 13 & $\begin{array}{l}\text { Phyllanthus emblica } \\
\text { (Amla) }\end{array}$ & Euphorbiaceae & $\begin{array}{l}\text { Vast number of medicinally important compounds present contributing it to } \\
\text { perform hepatoprotective, nephroprotective, immune booster, anti-hepatitic } \\
\text { and anti HIV agent. }\end{array}$ & Seyed (2019) \\
\hline 15 & $\begin{array}{l}\text { Piper longum } \\
\text { (Long Pepper) }\end{array}$ & Piperaceae & $\begin{array}{l}\text { Piperine, a bioinhacer as an active ingredient of Piper longum enhanced its } \\
\text { therapeutic values and used effectively to treat cough, cold, fever, jaundice } \\
\text { and as immunity tonic. }\end{array}$ & $\begin{array}{l}\text { Khushbu et al. } \\
\qquad(2011)\end{array}$ \\
\hline 16 & $\begin{array}{l}\text { Camellia sinensis } \\
\quad(\text { Green Tea })\end{array}$ & Theaceae & $\begin{array}{l}\text { Polyphenols such as epicatechingallate, epigallocatechin gallate and } \\
\text { gallocatechin- } 3 \text { gallate are reported as a potent drug against SARS CoV- } 2 \text { as } \\
\text { it inhibits main protease of virus required for its replication. However, in } \\
\text { vivo experimental results are required. }\end{array}$ & $\begin{array}{l}\text { Ghosh et al. } \\
\text { (2020) }\end{array}$ \\
\hline 17 & $\begin{array}{l}\text { Withania somnifera } \\
\text { (Indian Ginseng } \\
\text { orAshwagandha) }\end{array}$ & Solanaceae & $\begin{array}{l}\text { Bioactives such as withanolide } \mathrm{N} \text {, ashwagandanolide, withanoside } \mathrm{X} \text { and } \\
\text { dihydrowithaferin A are contributed to potent anti-inflammatory, antioxidant, } \\
\text { immunomodulatory and promising antiviral role against Covid-19. }\end{array}$ & $\begin{array}{l}\text { Chikhale et al. } \\
\qquad(2020)\end{array}$ \\
\hline 18 & Cinchona tree (Quina) & Rubiaceae & $\begin{array}{l}\text { Quinine, its major active compound having antiviral potency used to derive } \\
\text { a efficacious synthetic drug chloroquine to fight with covid-19 due to its } \\
\text { DNA intercalating property. }\end{array}$ & $\begin{array}{l}\text { Jahan \& Onay } \\
\qquad(2020)\end{array}$ \\
\hline 19 & Phaseolus vulgaris & Fabaceae & $\begin{array}{l}\text { Phytochemicals reported to have potent antiviral activity against HIV and } \\
\text { Drosophila } \mathrm{C} \text { virus apart from this phytochemicals also have significant } \\
\text { potency against novel corona virus due to its high binding affinity with main } \\
\text { protease and ACE2 protein. }\end{array}$ & Joshi et al. (2020) \\
\hline 20. & Petrselinum crispum & Apiaceae & $\begin{array}{l}\text { Apigenin as an active principle exhibited strong binding affinity towards } \\
\text { Covid-19 virus spike protein thus having potent antiviral activity. }\end{array}$ & $\begin{array}{l}\text { Subbaiyan et al. } \\
\text { (2020) }\end{array}$ \\
\hline
\end{tabular}




\subsection{Zingiber officinale (Ginger)}

It is rhizomatous plant of family Zingiberaceae, commonly used as spice in Indian culture as well as an important traditional medicine comprised of antiviral, antipyretic, antibacterial, antioxidant and antihypertensive pharmacological properties. Rathinavel et al. (2020) reported 6-Gingerol, one of bioactive compound of ginger to be used as an effective candidate against Covid-19 as it binds to several target protein of virus and reduce its pathogenicity.

\subsection{Cinnamomum zeylanicum (Cinnamon)}

Cinnamon bark (Lauraceae) one of the important flavouring spices used from several centuries, having a broad pharmacological efficacy against digestive, respiratory and gynaecological ailments. Further, cinnamon is also reported to have immunity strengthening property and cinnamon taken along with honey would also lead to drastic enhancement of immunity (Niphade et al., 2009). In addition cinnamon, world's frequently consuming spice, has also been reported to have significant antioxidant, antitumor and antiinflammatory potency due to its volatile bioactive components (Goel \& Mishra, 2020).

\subsection{Elettaria cardamomum (Cardamom)}

Cardamoms are capsule of dried fruit, belongs to family Zingiberaceae having a characteristic aroma due to its bioactive components and frequently reported to be used as spice and also having medicinal importance against asthma, diarrhea digestive and kidney disorders. Further, bioactive compounds of cardamomum are also reported to have anticancer, anti-oxidant, antifungal, antiviral, anti-inflammatory and gastroprotective therapeutic qualities (Ashok kumar et al., 2020)

\subsection{Piper nigrum (Black pepper)}

Piper nigrum, belongs to family Piperaceae, known as 'king of spices' which not only enhance flavour and taste of diet as spice but can also be recommended in Ayurveda as a potent medicine for broncho-pulmonary disorders, fever, neurological disorders as well as gastrointestinal problems (Stojanovic-Radic et al., 2019). Piperine, major bioactive of Piper nigrum responsible for its pungency, reported to have wide array of therapeutic potencies including anticarcinogenic, hepatoprotective, anti inflammatory, antioxidant, immunomodulatory and anti asthmatic. Further, Piperine also acts as bioenhancer which boost therapeutic potency of drugs through enhancing their bioavailability (Gorgani et al., 2017). Turmeric consumed together with black pepper reported to have 2000 times enhanced absorption rate.

\subsection{Illicium verum (Star anise)}

Star shape aromatic fruit frequently being used as culinary ingredient, also reported to have diverse therapeutic applications due to its bioactive compounds. As an important immunity booster it prepares body to resist against several viral diseases. Shikimic acid obtained from star anise is used to form drug against Influenza virus. Besides, Illicium verum is also having anti bacterial, antioxidant and anti inflammatory effects and widely used as remedy against cough, asthma, dysentery and arthritis (Patra et al., 2020).

\subsection{Myristica fragrans (Nutmeg)}

Myristica fragrans due to its magical sweet and spicy flavour, become one of the essential constituent in Indian kitchen since antiquity and also reported to have significant health values. Nutmeg due to having myristcine, myrcene, safrole, camphene, sabinene, linalool, 1,8-cineole and eugenol as its volatile constituent used as pain reliever, besides it is also having properties to treat stomach disorder, respiratory problems, cardiovascular problems as well as used as brain tonic, liver tonic and immunity booster (Upadhyay, 2020)

\section{Conclusion}

There are several Indian medicinal plants and their phytoconstituents that are safe and efficacious in alleviating pandemic situation as immunobooster, thereby, and preventing viral transmission. Hence, bioprospection and documentation of ethnomedicinal plants are needed in order to discover new wonder drugs against SARS CoV-2. Incorporation of nano-biotechnology and collaboration between pharmacologists, botanists, Ayurvedic practitioners and biotechnologists will boost the efficacy of the traditionally used plant based immunomodulators against Covid19 pandemic through enhancing their efficacy, bioavailability and practical applicability.

\section{Acknowledgements}

Authors are thankful to the University Grant Commission (UGC) [grant no.: 16-9(June 2018)/2019(NET/CSIR)], New Delhi, India for proving financial support.

\section{Conflicts of Interests}

The Author declares no conflict of interests.

\section{References}

Akram M, Tahir IM, Shah SMA, Mahmood Z, Altaf A, Ahmad K, Munir N, Daniyal M, Nasir S, Mehboob H (2018) Antiviral potential of medicinal plants against HIV, HSV, influenza, hepatitis, and coxsackie virus: A systematic review. Phytotherapy Research 32: 811-822.

Alanagreh LA, Alzoughool F, Atoum M (2020) The human coronavirus disease Covid-19: its origin, characteristics, and insights into potential drugs and its mechanisms. Pathogens 9: 1-11. 
Ali I, Alharbi OM (2020) COVID-19: Disease, management, treatment, and social impact. Science of the Total Environment 728:1-6.

Arshad MS, Khan U, Sadiq A, Khalid W, Hussain M, Yasmeen A, Asghar Z, Rehana H (2020) Coronavirus disease (Covid-19) and immunity booster green foods: A mini review. Food Science \& Nutrition 8: 3971-3976.

Ashokkumar K, Murugan M, Dhanya MK, Warkentin TD (2020) Botany, traditional uses, phytochemistry and biological activities of cardamom [Elettaria cardamomum (L.) Maton]-A critical review. Journal of Ethnopharmacology 10: 1-40.

Ayush (2020) Ayurveda's immunity boosting measures for self care during COVID 19 crisis. The Ministry of Ayurvedic, Yoga and Naturopathy, Unani, Siddha and Homeopathy (AYUSH), http://ayush.gov.in/event/ayurveda-immunity-boosting-measuresself-care-during-covid-19-crisis

Bailly C, Vergoten G (2020) Glycyrrhizin: An alternative drug for the treatment of COVID-19 infection and the associated respiratory syndrome? Pharmacology \& Therapeutics 214: 107618.

Banerjee A, Kulcsar K, Misra V, Frieman M, Mossman K (2019) Bats and coronaviruses. Viruses 11: 1-15.

Baravkar AA, Shende MV, Nalawade NA (2020) Corona Virus and COVID-19. International Journal of Research in Engineering, Science and Management 3: 558-561.

Batiha GE, Beshbishy AM, El-Mleeh A, Abdel-Daim MM, Devkota HP (2020) Traditional uses, bioactive chemical constituents, and pharmacological and toxicological activities of Glycyrrhiza glabra L.(Fabaceae). Biomolecules 10: 1-19.

Bhowmik D, Nandi R, Kumar D 2020 Evaluation of flavonoids as 2019-nCoV cell entry inhibitor through molecular docking and pharmacological analysis. ChemRxiv. Preprint https://doi.org/10.26434/chemrxiv.12071508.v1

Cascella M, Rajnik M, Cuomo A, Dulebohn SC, Di Napoli R (2020) Features, evaluation and treatment coronavirus (COVID19). InStatpearls [internet] StatPearls Publishing.

Chen L, Hu C, Hood M, Zhang X, Zhang L, Kan J, Du J (2020b) A Novel Combination of Vitamin C, Curcumin and Glycyrrhizic Acid Potentially Regulates Immune and Inflammatory Response Associated with Coronavirus Infections: A Perspective from System Biology Analysis. Nutrients 12: 1193.

Chen Y, Liu Q, Guo D (2020a) Emerging coronaviruses: genome structure, replication, and pathogenesis. Journal of medical virology 92: 418-23.
Chikhale RV, Gurav SS, Patil RB, Sinha SK, Prasad SK, Shakya A, Shrivastava SK, Gurav NS, Prasad RS (2020). Sars-cov-2 host entry and replication inhibitors from Indian ginseng: an in-silico approach. Journal of Biomolecular Structure and Dynamics 1-12.

Devansh M (2020) Possible Plant Based Medicines And Phytochemicals To Be Cure For Deadly Coronavirus COVID 19. World Journal of Pharmacy and Pharmaceutical Sciences 9: 531533 .

Dhama K, Saminathan M, Jacob SS, Singh M, Karthik K, Amarpal, Tiwari R, Sunkara LT, Malik YS, Singh RK (2015) Effect of immunomodulation and immunomodulatory agents on health with some bioactive principles, modes of action and potent biomedical applications. International Journal of Pharmacology 11(4): 253-290.

Dhama K, Karthik K, Khandia R, Munjal A, Tiwari R, Rana R, Khurana SK, Sana Ullah, Khan RU, Alagawany M, Farag MR, Dadar M, Joshi SK (2018) Medicinal and therapeutic potential of herbs and plant metabolites / extracts countering viral pathogens Current knowledge and future prospects. Current Drug Metabolism 19(3):236-263.

Dhama K, Khan S, Tiwari R, Sircar S, Bhat S, Malik YS, Singh KP, Chaicumpa W, Bonilla-Aldana DK, Rodriguez-Morales AJ (2020) Coronavirus Disease 2019-COVID-19. Clinical Microbiology Reviews 33(4): e00028-20. doi: 10.1128/CMR.00028-20.

Dibazar SP, Fateh S, Daneshmandi S (2014) Clove (Syzygium aromaticum) ingredients affect lymphocyte subtypes expansion and cytokine profile responses: An in vitro evaluation. Journal of food and drug analysis 22: 448-454.

Divya M, Vijayakumar S, Chen J, Vaseeharan B, Duran-Lara EF (2020) A review of South Indian medicinal plant has the ability to combat against deadly viruses along with COVID-19?. Microbial Pathogenesis 147:1-6.

Donma MM, Donma O (2020) The Effects of Allium Sativum on Immunity within the Scope of COVID-19 Infection. Medical Hypotheses 109934.

Florindo HF, Kleiner R, Vaskovich-Koubi D, Acúrcio RC, Carreira B, Yeini E, Tiram G, Liubomirski Y, Satchi-Fainaro R (2020) Immune-mediated approaches against COVID-19. Nature nanotechnology 13: 1-6.

Gangal N, Nagle V, Pawar Y, Dasgupta S (2020) Reconsidering Traditional Medicinal Plants to Combat COVID-19. AIJR Preprints 1-6 
Gautam S, Gautam A, Chhetri S, Bhattarai U (2020) Immunity Against COVID-19: Potential Role of Ayush Kwath. Journal of Ayurveda and Integrative Medicine 1-8.

Ghosh R, Chakraborty A, Biswas A, Chowdhuri S (2020) Evaluation of green tea polyphenols as novel corona virus (SARS $\mathrm{CoV}-2$ ) main protease (Mpro) inhibitors-an in silico docking and molecular dynamics simulation study. Journal of Biomolecular Structure and Dynamics 1-13.

Girija PL, Sivan N (2020) Ayurvedic treatment of COVID19/SARS-CoV-2: A case report. Journal of Ayurveda and Integrative Medicine 1-5.

Goel B, Mishra S (2020) Medicinal and Nutritional Perspective of Cinnamon: A Mini-review. European Journal of Medicinal Plants 31: $10-16$.

Gorgani L, Mohammadi M, Najafpour GD, Nikzad M (2017) Piperine - the bioactive compound of black pepper: from isolation to medicinal formulations. Comprehensive Reviews in Food Science and Food Safety 16: 124-140.

Gulcin I, Kaya R, Goren AC, Akincioglu H, Topal M, Bingol Z, Cetin Çakmak K, Ozturk Sarikaya SB, Durmaz L, Alwasel S (2019) Anticholinergic, antidiabetic and antioxidant activities of Cinnamon (Cinnamomum verum) bark extracts: polyphenol contents analysis by LC-MS/MS. International Journal of Food Properties 22:1511-1526.

Guo YR, Cao QD, Hong ZS, Tan YY, Chen SD, Jin HJ, Tan KS, Wang DY, Yan Y (2020) The origin, transmission and clinical therapies on coronavirus disease 2019 (COVID-19) outbreak-an update on the status. Military Medical Research 7: 1-10.

Gupta H, Gupta M, Bhargava S (2020a) Potential use of turmeric in COVID-19. Clinical and experimental Dermatology 45: 902-903.

Gupta S, Mishra KP, Ganju L (2017) Broad-spectrum antiviral properties of andrographolide. Archives of virology 162: 611-23.

Gupta S, Singh AK, Kushwaha PP, Prajapati KS, Shuaib M, Senapati S, Kumar S (2020b) Identification of potential natural inhibitors of SARS-CoV2 main protease by molecular docking and simulation studies. Journal of Biomolecular Structure and Dynamics 1-12.

Helmy YA, Fawzy M, Elaswad A, Sobieh A, Kenney SP, Shehata AA (2020) The COVID-19 pandemic: a comprehensive review of taxonomy, genetics, epidemiology, diagnosis, treatment, and control. Journal of Clinical Medicine 9: 1-29.

Huang C, Wang Y, Li X, Ren L, Zhao J, Hu Y, Zhang L, Fan G, Xu J, Gu X, Cheng Z (2020) Clinical features of patients infected with 2019 novel coronavirus in Wuhan, China. The lancet 395: 497-506.

Jahan I, Onay A (2020) Potentials of plant-based substance to inhabit and probable cure for the COVID-19. Turkish Journal of Biology 44: 228.

Jena AB, Kanungo N, Nayak V, Chainy GBN, Dandapat J (2020) Catechin and Curcumin interact with corona (2019-nCoV/SARSCoV2) viral S protein and ACE2 of human cell membrane: insights from Computational study and implication for intervention. 10.21203/rs.3.rs-22057/v1.

Jin Y, Yang H, Ji W, Wu W, Chen S, Zhang W, Duan G (2020) Virology, epidemiology, pathogenesis, and control of COVID-19. Viruses 12: 1-17.

Joshi T, Joshi T, Sharma P, Mathpal S, Pundir H, Bhatt V, Chandra, S (2020) In silico screening of natural compounds against COVID-19 by targeting Mpro and ACE2 using molecular docking. European Review for Medical and Pharmacological Sciences 24: 4529-4536.

Kaushik H, Singh VK (2020) mathematics of covid-19 in India and their possible control by Allium sativum (1.). Asian Journal of Advances in Medical Science 2: 21-27.

Kaushik S, Jangra G, Kundu V, Yadav JP, Kaushik S (2020) Antiviral activity of Zingiber officinale (Ginger) ingredients against the Chikungunya virus. Virus Disease 31: 270-276.

Khan MH, Yadava PS (2010) Antidiabetic plants used in Thoubal district of Manipur, Northeast India. Indian Journal of Traditional Knowledge 9: 510-514.

Khushbu C, Roshni S, Anar P, Carol M, Mayuree P (2011) Phytochemical and therapeutic potential of Piper longum Linn a review. International journal of research in Ayurveda and Pharmacy 2: 157-61.

Krupanidhi S, Abraham Peele K, Venkateswarulu TC, Ayyagari VS, Nazneen Bobby M, John Babu D, Venkata Narayana A, Aishwarya G (2020) Screening of phytochemical compounds of Tinospora cordifolia for their inhibitory activity on SARS-CoV-2: an in silico study. Journal of Biomolecular Structure and Dynamics $1-5$.

Kumar D, Arya V, Kaur R, Bhat ZA, Gupta VK, Kumar V (2012) A review of immunomodulators in the Indian traditional health care system. Journal of Microbiology, Immunology and Infection 45: $165-184$.

Lau KM, Lee KM, Koon CM, Cheung CS, Lau CP, Ho HM, Lee MY, Au SW, Cheng CH, Bik-San Lau C, Tsui SK (2008) 
Immunomodulatory and anti-SARS activities of Houttuynia cordata. Journal of Ethnopharmacology 118: 79-85.

Li Y, Liu X, Guo L, Li J, Zhong D, Zhang Y, Clarke M, Jin R (2020) Traditional Chinese herbal medicine for treating novel coronavirus (COVID-19) pneumonia: protocol for a systematic review and meta-analysis. Systematic Reviews 9: 75. doi.org/10.1186/s13643-020-01343-4.

Lin Q, Zhao S, Gao D, Lou Y, Yang S, Musa SS, Wang MH, Cai Y, Wang W, Yang L, He D (2020) A conceptual model for the outbreak of Coronavirus disease 2019 (COVID-19) in Wuhan, China with individual reaction and governmental action. International Journal of Infectious Diseases 93: 211-216.

LuoLiu P, Li J (2020) Pharmacologic perspective: glycyrrhizin may be an efficacious therapeutic agent for COVID19. International Journal of Antimicrobial Agents 55: 105995.

Mahapatra AD, Bhowmik P, Banerjee A, Das A, Ojha D, Chattopadhyay D (2019) Ethnomedicinal Wisdom: An Approach for Antiviral Drug Development. In New Look to Phytomedicine, Academic Press 35-61.

Mahima Verma AK, Tiwari R, Karthik K, Chakraborty S, Deb R, Dhama K (2013) Nutraceuticals from fruits and vegetables at a glance: a review. Journal of Biological Sciences 13(2): 38-47.

Malik YS, Kumar N, Sircar S, Kaushik R, Bhat S, Dhama K, Gupta P, Goyal K, Singh MP, Ghoshal U, El Zowalaty ME, O R V, Yatoo MI, Tiwari R, Pathak M, Patel SK, Sah R, RodriguezMorales AJ, Ganesh B, Kumar P, Singh RK (2020) Coronavirus Disease Pandemic (COVID-19): Challenges and a Global Perspective. Pathogens 9(7):519.

Mani JS, Johnson JB, Steel JC, Broszczak DA, Neilsen PM, Walsh KB, Naiker M (2020) Natural product-derived phytochemicals as potential agents against coronaviruses: A review. Virus Research 284: 197989. doi: 10.1016/j.virusres.2020.197989.

Maurya DK, Sharma D (2020) Evaluation of traditional ayurvedic preparation for prevention and management of the novel Coronavirus (SARS-CoV-2) using molecular docking approach. ChemRxiv 1-42.

Maurya H, Rao V (2019) The Favorable Role of Alkaloids from Vitex negundo in the Management of Human Ailments. Annals of Clinical pharmacology \& Toxicology 1: 8-12.

Mirzaie A, Halaji M, Dehkordi FS, Ranjbar R, Noorbazargan H (2020) A narrative literature review on traditional medicine options for treatment of corona virus disease 2019 (COVID-19). Complementary Therapies in Clinical Practice 40: 1-8.
Mishra LC, Singh BB, Dagenais S (2001) Ayurveda: a historical perspective and principles of the traditional healthcare system in India. Alternative Therapies in Health and Medicine 7: 36-43.

Mittal M, Gupta N, Parashar P, Mehra V, Khatri M (2014) Phytochemical evaluation and pharmacological activity of Syzygium aromaticum: a comprehensive review. International Journal of Pharmacy and Pharmaceutical Sciences 6: 67-72.

Murck H (2020) Symptomatic Protective Action of Glycyrrhizin (Licorice) in COVID-19 Infection? Frontiers in Immunology 11:1239.

Murthy SM, Vidyasagar GM (2013) Traditional knowledge on medicinal plants used in the treatment of respiratory disorders in Bellary district, Karnataka, India. Indian Journal of Natural Products and Resources 4: 189-193.

Nayak P, Thirunavoukkarasu M (2016) A review of the plant Boerhaavia diffusa: Its chemistry, pharmacology and therapeutical potential. The Journal of Phytopharmacol 5: 83-92.

Ngwa W, Kumar R, Thompson D, Lyerly W, Moore R, Reid TE, Lowe H, Toyang N (2020) Potential of Flavonoid-Inspired Phytomedicines against COVID-19. Molecules 25: 2707. doi: 10.3390/molecules25112707

Niphade SR, Asad M, Chandrakala GK, Toppo E, Deshmukh P (2009) Immunomodulatory activity of Cinnamomum zeylanicum bark. Pharmaceutical Biology 47:1168-1173.

Niraj S, Varsha S (2020) A review on scope of immunomodulatory drugs in Ayurveda for prevention and treatment of Covid-19. Plant Science Today 7: 417-23.

Pandey MM, Rastogi S, Rawat AK (2013) Indian traditional ayurvedic system of medicine and nutritional supplementation. Evidence-Based Complementary and Alternative Medicine 2013:1-12.

Panyod S, Ho CT, Sheen LY (2020) Dietary therapy and herbal medicine for COVID-19 prevention: A review and perspective. Journal of Traditional and Complementary Medicine 10: 420-427. doi: 10.1016/j.jtcme.2020.05.004.

Patra JK, Das G, Bose S, Banerjee S, Vishnuprasad CN, del Pilar Rodriguez-Torres M, Shin HS (2020) Star anise (Illicium verum): Chemical compounds, antiviral properties, and clinical relevance. Phytotherapy Research 34: 1248-1267.

Rabaan AA, Al-Ahmed SH, Sah R, Tiwari R, Yatoo MI, Patel SK, Pathak M, Malik YS, Dhama K, Singh KP, Bonilla-Aldana DK, Haque S, Martinez-Pulgarin DF, Rodriguez-Morales AJ, Leblebicioglu H. (2020a) SARS-CoV-2/COVID-19 and advances 
in developing potential therapeutics and vaccines to counter this emerging pandemic. Annals of Clinical Microbiology and Antimicrobials 19(1):40. doi: 10.1186/s12941-020-00384-w.

Rabaan AA, Al-Ahmed SH, Haque S, Sah R, Tiwari R, Malik YS, Dhama K, Yatoo MI, Bonilla-Aldana DK, Rodriguez-Morales AJ (2020b) SARS-CoV-2, SARS-CoV, and MERS-CoV: a comparative overview. Le Infezioni in Medicina 28: 174-84.

Rahal A, Mahima, Verma AK, Kumar A, Tiwari R, Kapoor S, Chakraborty S, Dhama K (2014) Phytonutrients and nutraceuticals in vegetables and their multi-dimensional medicinal and health benefits for humans and their companion animals: A review. Journal of Biological Science 14(1): 1-19.

Rastogi S, Pandey DN, Singh RH (2020) COVID-19 Pandemic: A pragmatic plan for Ayurveda Intervention. Journal of Ayurveda and Integrative Medicine 2-5 https://doi.org/10.1016/j.jaim.2020.04.002.

Rathinavel T, Palanisamy M, Palanisamy S, Subramanian A, Thangaswamy S (2020) Phytochemical 6-Gingerol-A promising Drug of choice for COVID-19. International Journal of Advanced Science and Engineering 6: 1482-1489.

Rodriguez-Morales AJ, Bonilla-Aldana DK, Tiwari R, Sah R, Rabaan AA, Dhama K (2020) COVID-19, an emerging coronavirus infection: current scenario and recent developments an overview. Journal of Pure and Applied Microbiology 14(1): 05 12. https://doi.org/10.22207/JPAM.14.1.02

Ren JL, Zhang AH, Wang XJ (2020) Traditional Chinese medicine for COVID-19 treatment. Pharmacological research 155: 1-2.

Sahoo JP, Mohapatra U, Mishra AP, Chandra K (2020) Turmeric (Haldi)-A strapping strategy for enhancing the immune system to reduce the effect of SARS-CoV-2. Food and Scientific reports 1:10-12.

Sen S, Chakraborty R (2017) Revival, modernization and integration of Indian traditional herbal medicine in clinical practice: Importance, challenges and future. Journal of traditional and complementary medicine $7: 234-44$.

Seyed MA (2019) A comprehensive review on Phyllanthus derived natural products as potential chemotherapeutic and immunomodulators for a wide range of human diseases. Biocatalysis and Agricultural Biotechnology 17: 529-37.

Sharma R, Martins N, Kuca K, Chaudhary A, Kabra A, Rao MM, Prajapati PK (2019) Chyawanprash: a traditional Indian bioactive health supplement. Biomolecules 9: 1-24.

Shree P, Mishra P, Selvaraj C, Singh SK, Chaube R, Garg N, Tripathi YB (2020) Targeting COVID-19 (SARS-CoV-2) main protease through active phytochemicals of ayurvedic medicinal
plants-Withania somnifera (Ashwagandha), Tinospora cordifolia (Giloy) and Ocimum sanctum (Tulsi)-a molecular docking study. Journal of Biomolecular Structure and Dynamics 1-14.

Singhal T (2020) A review of coronavirus disease-2019 (COVID19). The Indian Journal of Pediatrics 13:1-6.

Sinha SK, Prasad SK, Islam MA, Gurav SS, Patil RB, AlFaris NA, Aldayel TS (2020) AlKehayez NM, Wabaidur SM, Shakya A. Identification of bioactive compounds from Glycyrrhiza glabra as possible inhibitor of SARS-CoV-2 spike glycoprotein and non-structural protein-15: a pharmacoinformatics study. Journal of Biomolecular Structure and Dynamics 1-15.

Stojanovic-Radic Z, Pejcic M, Dimitrijevic M, Aleksic A, V Anil Kumar N, Salehi B, C Cho W, Sharifi-Rad J (2019) Piperine-A Major Principle of Black Pepper: A review of its bioactivity and studies. Applied Sciences 9: 1-29.

Subbaiyan A, Ravichandran K, Singh SV, Sankar M, Thomas P, Dhama K, MalikYS, Singh RK and Chaudhuri $P$ (2020) In silico Molecular Docking Analysis Targeting SARS-CoV-2 Spike Protein and Selected Herbal Constituents. Journal of Pure and Applied Microbiology 14: 989-998. doi: 10.22207/JPAM.14.SPL1.37.

Tiwari R, Latheef SK, Ahmed I, Iqbal H, Bule MH, Dhama K, Samad HA, Karthik K, Alagawany M, El-Hack ME, Yatoo MI, Farag MR (2018) Herbal Immunomodulators - A Remedial Panacea for Designing and Developing Effective Drugs and Medicines: Current Scenario and Future Prospects. Current Drug Metabolism 19(3): 264-301.

Tripathi MK, Singh P, Sharma S, Singh TP, Ethayathulla AS, Kaur P (2020) Identification of bioactive molecule from Withania somnifera (Ashwagandha) as SARS-CoV-2 main protease inhibitor. Journal of Biomolecular Structure and Dynamics 1-14.

Ul Qamar MT, Alqahtani SM, Alamri MA, Chen LL (2020) Structural basis of SARS-CoV-2 3CL ${ }^{\text {pro }}$ and anti-COVID-19 drug discovery from medicinal plants. Journal of Pharmaceutical Analysis 10: 313-319. doi: 10.1016/j.jpha.2020.03.009.

Umashanker M, Shruti S (2011) Traditional Indian herbal medicine used as antipyretic, antiulcer, anti-diabetic and anticancer: A review. International journal of research in pharmacy and chemistry 1: 1152-1159.

Uniyal SK, Singh KN, Jamwal P, Lal B (2006) Traditional use of medicinal plants among the tribal communities of Chhota Bhangal, Western Himalaya. Journal of ethnobiology and ethnomedicine 2: 1-8.

Upadhyay RK (2020) Thermal-Aroma-Organic-Carbon-Fusion therapy: An open air conventional method for clearance of nasal air passage, trachea, lungs and immunity boosting against Influenza Virus. International Journal of Zoological Investigations 6: 71-93. 
Vellingiri B, Jayaramayya K, Iyer M, Narayanasamy A, Govindasamy V, Giridharan B, Ganesan S, Venugopal A, Venkatesan D, Ganesan H, Rajagopalan K (2020) COVID-19: A promising cure for the global panic. Science of the Total Environment 725: 1-18.

Wu F, Zhao S, Yu B, Chen YM, Wang W, Hu Y, Song ZG, Tao ZW, Tian JH, Pei YY, Yuan ML (2020) Complete genome characterisation of a novel coronavirus associated with severe human respiratory disease in Wuhan, China. bioRxiv 1-32.

Xu J, Zhang Y (2020) Traditional Chinese medicine treatment of COVID-19. Complementary Therapies in Clinical Practice 39: 101165.
Yatoo MI, Hamid Z, Parray OR, Wani AH, Ul Haq A, Saxena A, Patel SK, Pathak M, Tiwari R, Malik YS, Sah R, Rabaan AA, Rodriguez Morales AJ, Dhama K. (2020) COVID-19 - Recent advancements in identifying novel vaccine candidates and current status of upcoming SARS-CoV-2 vaccines. Human Vaccines and Immunotherapeutics 1-14. doi: 10.1080/21645515.2020.1788310.

Zhang L, Yu J, Zhou Y, Shen M, Sun L (2020) Becoming a Faithful Defender: Traditional Chinese Medicine against Coronavirus Disease 2019 (COVID-19). The American Journal of Chinese Medicine 1-15. https://doi.org/10.1142/S0192415X2050038 